\title{
Experimentelle Untersuchungen
} über die ökologische Wirkung der Strömungsgeschwindigkeit auf die Lebensgemeinschaften des fliessenden Wassers

\author{
Doctoral Thesis \\ Author(s): \\ Zimmermann, Peter \\ Publication date: \\ 1961
}

Permanent link:

https://doi.org/10.3929/ethz-a-000092334

Rights / license:

In Copyright - Non-Commercial Use Permitted 


\title{
Experimentelle Untersuchungen über die ökologische Wirkung der Strömungs- geschwindigkeit auf die Lebensgemeinschaften des fliessenden Wassers
}

\author{
Von der \\ EIDGENÖSSISCHEN TECHNISCHEN \\ HOCHSCHULE IN ZÜRICH \\ zur Erlangung \\ der Würde eines Doktors der \\ Naturwissenschaften \\ genehmigte \\ PROMOTIONSARBEIT \\ Vorgelegt von \\ PETER ZIMMERMANN \\ diplomierter Naturwissenschafter \\ von Aarau \\ Referent: Herr Prof. Dr. O. Jaag \\ Korreferent: Herr Prof. Dr. E. Gäumann
}

Buchdruckerei Birkhäuser AG, Basel

I 9 GI 
zeigen, dass im Bereich des fliessenden Wassers Kräfte wirksam werden, die unbedingt Berücksichtigung finden müssen.

\section{F. Zusammenfassung}

I. Drei Vorflutmodelle eines im Gefälle verstellbaren Rinnensystems, Bestandteil der Versuchsanlage der Eidgenössischen Anstalt für Wasserversorgung, Abwasserreinigung und Gewässerschutz in Zürich, wurden unter identischen chemischen Bedingungen, aber mit unterschiedlichen Fliessgeschwindigkeiten von 5,20 und $80 \mathrm{~cm} / \mathrm{s}$ betrieben. Mit der Abwasserkonzentration als Parameter wurde eine Serie von vier Versuchen durchgefuihrt, mit dem Ziele, die ökologische Wirkung der Wasserbewegung bei verschiedener Abwasserlast zu prüfen.

2. Die Rinnen repräsentierten in den Versuchen sommerkalte, sauerstoffreiche, leicht alkalische Bäche des schweizerischen Mittellandes mit geringem Karbonatgehalt und einfacher Kiessohle.

3. In jedem Versuch bildete sich bei jeder Fliessgeschwindigkeit eine charakteristische Biozönose, die sich von denjenigen aller andern Rinnen deutlich unterschied.

4. Auf Grund der Versuchsanordnung kann für die arten- und abundanzmässige Verschiedenheit der Biozönosen innerhalb eines Versuches nur die Strömungsgeschwindigkeit des Wassers verantwortlich gemacht werden.

5. Als Ursache für dieses Ergebnis fallen folgende Umstände in Betracht :

Die unter den wasserbewohnenden Organismen unterschiedlich ausgeprägte «Anpassung der Reaktionsbereitschaft» [2] gegenüber der Strömung.

Die unterschiedliche Fähigkeit der Organismen, sich in der Strömung anzusiedeln, ihr Widerstand zu leisten oder ihr aktiv entgegenzuarbeiten und sich in ihr fortzupflanzen und auszubreiten.

Die für manche spezialisierte Arten lebensnotwendige Funktion der Strömung als Zubringer von Sauerstoff, Nährstoffen und Nahrungspartikeln und als Ableiter der Stoffwechselprodukte. Daraus resultieren z. T. die für verschiedene Arten scharf und eng umgrenzten Ansprüche an die Stärke der Fliessgeschwindigkeit.

Die ausgeprägten Taxien vieler Fliesswasserorganismen.

Das durch die Strömung geformte und bestimmte Substrat, der Gewässergrund. 
Der direkte Einfluss der Fliessgeschwindigkeit auf die physiographischen Eigenschaften der Totwässer.

6. Die ökologischen Ansprüche der rund so in nennenswerter Menge aufgetretenen Arten werden auf Grund der im Versuch gegebenen Bedingungen umrissen und graphisch dargestellt. Danach zeigten nur einige wenige Arten eine strömungsunabhängige Reaktion auf den Belastungsgrad mit Abwasser. Alle übrigen Formen sprachen auf den Strömungsreiz stärker oder doch ebenso stark an wie auf den Chemismus.

7. Die Beurteilung der Biozönosen nach dem Saprobiensystem führt zu einer unterschiedlichen Einschätzung chemisch absolut gleichwertiger, aber in der Strömung verschiedener Vorflutmodelle. Hier liegt die Ursache indessen nicht bei der Strömung, sondern beim Beurteilungssystem, indem das Auftreten eines Organismus je nach Fliessgeschwindigkeit für diese oder jene Saprobiestufe sprechen kann.

8. Diese Verhältnisse sind bei der biologischen Fliesswasseranalyse gebührend zu berücksichtigen, was nur geschehen kann, wenn die mittlere Fliessgeschwindigkeit an der Probenahmestelle bekannt ist und bei der Auswertung in Rechnung gestellt wird.

\section{Summary}

The present paper describes a study of ecological problems in flowing water. Model experiments have been carried out in channels which are part of the «Tüffenwies» research facilities of the Federal Institute for Water Supply, Semage Purification and Water Pollution Control. These channels are $75 \mathrm{~m}$ long, $20 \mathrm{~cm}$ wide and $\mathrm{I} 5 \mathrm{~cm}$ deep, made of asbestos cement and have a gravel bottom. Flow velocities in three of these channels were kept at 5 , 20 and $80 \mathrm{~cm}$ per second respectively. The conditions corresponded to those of a «summercool» (sommerkalt) brook of northern Switzerland: slightlyy alkaline and well oxygenated water with a low carbonat content, refers to brooks carrying springs or ground water.

The water in the three channels was evenly contaminated with a certain concentration of sewage. Four experiments were carried out, each with a different concentration of sewage.

The biocoenoses that developed during each of these four experiments showed characteristic qualitative and quantitative differences in the three channels. It was therefore concluded that flow velocity is ecologically very important. The following factors are considered responsible for this: 
I. The varying ability of organisms to move about ant to reproduce in flowing water.

2. Many specialized forms can obtain oxygen and/or food only in flowing water. They usually depend upon the current also for removal of their waste products. As a result there are species whose existence depends on a more or less sharply defined flow velocity.

3. Pronounced taxes of many lotic organisms.

4. Certain organisms prefer certain stream-bed topographies, which, in turn, are largely affected by the flow velocity of the water.

5. The direct effect of the flow velocity upon the physiographic properties of dead waters.

Dead waters represent biotopes with characteristic features. Their chemistry is directly related to the flow velocity of the stream. Strong currents favor a better exchange with the stream and the chemistry of the two are therefore more similar. Exchange decreases with decreasing flow velocity. This may lead, in extreme cases, to anaerobiosis in the dead water.

At one given degree of contamination with sewage, developing biocoenoses in the different channels seem to indicate different degrees of contamination. In general, high flow velocities tend to favor the development of a biocoenosis of a lower saprobic stage (Saprobiestufe). In other words, the biocoenosis in a fast stream will be somewhat similar to that of a slower stream which is less contaminated with sewage. This indicates clearly that the saprobic system (Saprobiensystem) takes flow velocities only insufficiently into account.

Ecological requirements of some so important species are described and plotted. Only few show a relatively flow-velocity independent reaction to the degree of contamination with sewage. All the others are equally or more sensitive to flow velocity than to water contamination. Flow velocity, therefore, is in many cases a more important ecological than the chemistry and has to be taken into account in biological analyses of flowing waters.

\section{LITERATURVERZEICHNIS}

[I] АмвӥHL, H., Mitt. Lebensmittelunt. Hyg. 49, 24I (1958).

[2] AмвӥнL, H., Schweiz. Z. Hydrol XXI, I33 (1959).

[3] Blöchliger, G., und Husmann, W., Schwciz. Z. Hydrol. VIII, 55 (1939).

[4] Edmondson, W. T., Freshwater Biology (Washington 1959).

[S] EINSEle, W., Österr. Fischerei 1, H. 2 (I960). 